\title{
ПУТИ СНИЖЕНИЯ ВРЕДНЫХ ВОЗДЕЙСТВИЙ КВАРЦЕВОГО ПРОИЗВОДСТВА НА ОКРУЖАНОЩУЮО СРЕДУ
}

\author{
ИСАЕВ В.Я., ОРЕШНИКОВА Н.Г. \\ Московский государственный горный университет \\ Ленинский проспект, 6, ГСП-1, 117935 Москва, Россияя
}

Для современного кварцевого производства проблемы снижения загрязнения окружающей среды исключительно актуальны практически на всех стапиях традиционных технологий. Добычные работы (отбойка от массива), первичная подготовка (дробление), обогатительные процессы (классификация, измельчение) сопровождаются значительным выходом кварцевой пыли, а глубокое обогащение кварца не может быть реалхззовано без использования неорганических кислот (РСдб PA). Кроме того, из-за щизкой эффективности обогащения объем отходов кварцевого производства значительно превышает объем конечной продукции (выход кварцевого концентрата в лучшем случае составляет 30\%).

Новая технология переработки жкивного кварца, основанная на его модификационной термообработке $(1,2,3)$, в значительной мере способствует решению этих проблем.

Принщипиальным отличем технологии модификационной термообработки кварца от классияеских обогатительных схем яляется отсуствие измельчительных операций (до класса $0,1-0,4$ мм), так как максимапный выход кристобалита постигается при работе на сырье средне- и крупнозернистых классов (7-20 мМ, 20 80 мм). Как следствие, этим достигается резкое снижение кварцевой пыли.

По предлагаемой технологии, в связи с особенностями строения кристобалита и конщентращией примесей на гранищах микро- и макродефектов зерен (каналов, пор, микротрещин), расход неорганических кислот для глуокой очистки промтродукта может быть сведен $\mathrm{k}$ минимуму. В ряде слудаев вместо неорганических кислот эффективнее использовать обработку кристобального продукта в электрофизических полях с последуюшим удалением примесей парами кислот, циркулируюиих в закрытом объеме.

Предлагаемая технологкя переработки кварца в сравнении с традиционными может быть квалифицирована как безотходная, так как суммарный выход брака и некондиционньх продуктов составлтет единицы процентов.

\section{JITEPATYPA}

1. Исаев В.А. Физико-техническое обоснование новой технологии переработки непрозрачньх разновидностей кварца. // Горный йнформационно-аналический бюллетень. - М.: МГГУ, N 5, 1997, с. 95-102.

2. Issaev V., Oreshnikova N. Extraction of Crystobalit from Milky-White Forms of Quartz Stuff. - Proceeding International Conference. - Environment. Technology. Resources. - Rezekne: RHEI, 1998, p. 24 - 35.

3. Исаев В.А., Орешникова Н.Г. Технология переработки непрозрачньгх разновидностей кварца. // Каталог научно-технических разработок. - М.: МГТУ, 1999, с. 54. 